\title{
PENGARUH PELIMPAHAN WEWENANG, ALOKASI ANGGARAN DAN KEPEMIMPINAN TERHADAP KINERJA KECAMATAN DI KABUPATEN GARUT
}

\author{
Jujun Juhana ${ }^{1}$, Sadu Wasistiono ${ }^{2}$, Irwan Tahir, Kusworo ${ }^{4}$ \\ ${ }^{1,2,3,4}$ Institut Pemerintahan Dalam Negeri (IPDN) \\ Email: jujun.juhana@gmail.com
}

\begin{abstract}
Abstrak
Penelitian ini membahas tentang pengaruh pelimpahan wewenang, alokasi anggaran dan kepemimpinan terhadap kinerja kecamatan di Kabupaten Garut, Provinsi Jawa Barat, Indonesia. Penelitian menggunakan pendekatan kuantitatif dengan mengambil sampel sebanyak 286 responden dari populasi 1003 orang. Pengumpulan data dalam penelitian ini menggunakan penyeberan kuesioner. Teknik analisis data menggunakan analisis SEM. Besarnya pengaruh pelimpahan wewenang terhadap kinerja kecamatan mencapai 0,754 ditentukan oleh keinginan politik bupati untuk mendelegasikan sebagian kewenangan pemerintahan kepada camat, kemauan politik Bupati untuk menjadikan kecamatan sebagai pusat pelayanan masyarakat, kelegowoan lembaga teknis daerah untuk melimpahkan sebagian kewenangan teknis yang dapat dijalankan oleh Camat, dukungan anggaran dan personil untuk menjalankan kewenangan yang telah didelegasikan. Besarnya pengaruh alokasi anggaran terhadap kinerja kecamatan yang mencapai 0,651 ditentukan oleh komprehensif dan disiplin, fleksibilitas, terprediksi, kejujuran, informasi, transparansi dan akuntabilitas. Besarnya pengaruh kepemimpinan terhadap kinerja kecamatan yang mencapai 0,655 ditentukan oleh bimbingan dan arahan yang diberikan Camat, perilaku hubungan camat dengan perangkat kecamatan, dan level kesiapan perangkat kecamatan.
\end{abstract}

Kata Kunci: Pelimpahan Wewenang, Alokasi Anggaran, Kepemimpinan, Kinerja.

\section{Abstract}

This study discusses the influence of delegation of authority, budget allocation and leadership to the performance of sub-districts in Garut Regency, West Java Province, Indonesia. The study uses a quantitative approach by taking a sample of 286 respondents from a population of 1003 people. Data collection in this study using questionnaires. Data analysis techniques using SEM analysis. The magnitude of the influence of delegation of authority on sub-district performance reached 0.754 determined by the political will of the district head to delegate part of government authority to the sub-district head, the political will of the district head to make the sub-district the center of community service, regional technical institutions' delegation to delegate part of the technical authority that can be carried out by the district head, budget support and personnel to exercise delegated authority. The magnitude of the effect of budget allocations on a sub-district performance that reaches 0.651 is determined by comprehensive and disciplined, flexibility, predictability, honesty, information, transparency, and accountability. The amount of leadership influence on a sub-district performance that reaches 0.655 is determined by the guidance and direction given by the sub-district head, the behavior of the sub-district head's relationship with the sub-district apparatus, and the level of readiness of the sub-district apparatus.

Keywords: Delegation of Authority, Budget Allocation, Leadership, Performance.

JURNAL PAPATUNG: Vol. 3 No. 1 Tahun 2020 


\section{A. PENDAHULUAN}

Indonesia merupakan negara yang kaya akan sumber daya alam. Sumber daya alam yang ada di Indonesia seperti minyak dan gas bumi yang berlimpah, air mineral dari pegunungan, jenis tumbuhan dan hewan yang beraneka ragam, serta tanah yang subur. Salah satu wilayah yang kaya akan sumber daya alam di Indonesia adalah Provinsi Riau. Hampir semua kekayaan alam dimiliki provinsi ini. Perut bumi Provinsi Riau mengandung minyak bumi, batubara, emas, timah dan bahan tambang lainnya. Sementara di atasnya terhampar kekayaan hutan, perkebunan dan pertanian dalam arti luas.

Setiap Satuan Kerja Perangkat Daerah (SKPD), termasuk Kantor Kecamatan, memiliki wewenang tertentu untuk melaksanakan tugas dan fungsi organisasi. Kewenangan diartikan sebagai hak untuk bertindak atau untuk memerintah orang lain untuk bertindak, ke arah pencapaian tujuan organisasi (Stoner, dkk., 1996, Kaho, 2002; Robbin, 1994:275). Dalam pandangan organisasi modern yang dikemukakan Weber (dalam Sutarto, 1995), tipe ideal suatu organisasi ditandai oleh adanya hirarki atau pendelegasian wewenang, pembagian tugas yang jelas, aturan atau prosedur kerja serta kualifikasi personil.

Delegasi adalah proses penyerahan pekerjaan kepada bawahan. Pekerjaan yang diserahkan adalah pekerjaan yang berada di dalam bidang tanggung jawab seorang manajer. Tanggung jawab terakhir masih terletak pada manajer itu, dan pada gilirannya ia tetap akan dianggap bertanggung jawab oleh atasannya yang lebih tinggi (Taylor, 1989; Ndraha, 1983; Kaho, 2002). Sementara, kekuasaan itu sendiri adalah kemampuan yang membuat seseorang atau orang lain untuk melakukan atau tidak melakukan sesuatu sesuai keinginannya (Wasistiono, 2004; Terry, 1960; Strauss \& Sayles, 1981).

Pendelegasian kewenangan bukan hanya sekedar memindahkan kewenangan, melainkan dalam rangka meningkatkan efektivitas dan efisiensi pelayanan kepada masyarakat serta penggunaan dana dan fasilitas publik untuk kepentingan publik. Selain itu, pendelegasian kewenangan tersebut harus dapat memenuhi dan meningkatkan rasa keadilan masyarakat, termasuk didalamnya memperoleh fasilitas dan akses yang setara, terutama untuk kelompok masyarakat yang selama ini terpinggirkan. Pada sisi lain, pendelegasian kewenangan harus mampu menjadi pengungkit kegiatan ekonomi masyarakat sehingga menjadi lebih produktif. Pendelegasian kewenangan jangan sampai memperpanjang jenjang birokrasi dan menciptakan ekonomi biaya tinggi yang membuat masyarakat menjadi tidak produktif dan kalah bersaing dengan mancanegara. 
Bila pendelegasian wewenang yang dimaksud dikaitkan dengan penyelenggaraan sistem pemerintahan, maka pendelegasian atau pelimpahan wewenang tersebut tercakup dalam implementasi kebijakan desentralisasi dan otonomi daerah. Misalnya, pendelegasian atau pelimpahan wewenang dari Kepala Daerah kepada Camat untuk melaksanakan urusanurusan pemerintahan tertentu, yang dinilai lebih efektif atau lebih efisien bila dilaksanakan oleh Camat beserta perangkat kecamatan. Pelimpahan wewenang yang dimaksud bisa terkait dengan penyelenggaraan pelayanan public yang dimonopoli oleh Negara seperti pelayanan perizinan; dan bisa juga terkait dengan penyelenggaraan urusan pemerintahan lainnya yang menjadi kewajiban masing-masing daerah. Pelimpahan wewenang yang demikian itu tampaknya berlangsung juga dalam penyelenggaraan Pemerintahan Daerah Kabupaten Garut.

Menurut Wasistiono (2001), pelaksanakan wewenang bupati/walikota yang telah didelegasikan kepada camat, memerlukan dukungan anggaran. Selain itu, untuk menjalankan kewenangan yang telah didelegasikan kepadanya, camat memerlukan dukungan personil yang cukup. Selanjutnya, untuk menjalankan wewenang yang telah didelegasikan kepadanya, camat memerlukan dukungan logistik. Jumlah dan kualitas logistik yang diberikan kepada camat disesuaikan dengan tingkat kebutuhan yang ditentukan oleh tipologinya.

Dengan kebijakan penyelenggaraan pemerintahan kecamatan yang demikian itu, maka peningkatan kinerja kecamatan di Kabupaten Garut penting sekali karena terdapat sejumlah kelemahan dan kekurangan yang menyebabkan kinerja kecamatan menjadi tidak optimal. Belum optimalnya kinerja kecamatan di Kabupaten Garut diduga dipengaruhi oleh beberapa faktor, diantaranya pelimpahan wewenang, alokasi anggaran dan kepemimpinan. Berdasarkan urian di atas, maka tujuan penelitian ini adalah untuk menganalisis pengaruh pelimpahan wewenang, alokasi anggaran dan kepemimpinan terhadap kinerja kecamatan di Kabupaten Garut, Provinsi Jawa Barat.

\section{B. TINJAUAN PUSTAKA}

Belum optimalnya kinerja Kecamatan tampak menjadi suatu fenomena kinerja pelayanan public yang berkorelasi dengan berbagai variabel. Di antara sejumlah variabel yang berkorelasi atau mempengaruhi, diasumsikan bahwa pelimpahan wewenang, alokasi anggaran, dan kepemimpinan merupakan tiga variabel yang berpengaruh positif (searah) terhadap kinerja kecamatan.

Asumsi yang menyatakan bahwa pelimpahan wewenang berpengaruh terhadap kinerja kecamatan adalah pendapat Handoko (dalam Kaho, 2002) yang mengatakan bahwa dalam 
proses pendelegasian wewenang ada empat kegiatan yang berlangsung masing-masing: 1) Pendelegasi menetapkan dan memberikan tujuan dan tugas kepada bawahan; 2) Pendelegasi melimpahkan wewenang yang diperlukan untuk mencapai tujuan dan tugas; 3) Penerima delegasi, baik implisit atau eksplisit menimbulkan kewajiban atau tanggung jawab; 4) Pendelegasi menerima pertanggungjawaban bawahan untuk hasil-hasil yang dicapai.

Dengan dukungan pendapat tersebut, selanjutnya variabel Pelimpahan Wewenang dipandang sebagai penyerahan kewenangan pemerintahan dari Bupati Garut kepada Camat yang dinyatakan dengan keinginan politik Bupati untuk mendelegasikan sebagian kewenangan pemerintahan kepada Camat, kemauan politik Bupati untuk menjadikan kecamatan sebagai pusat pelayanan masyarakat, kelegowoan lembaga teknis daerah untuk melimpahkan sebagian kewenangan teknis yang dapat dijalankan oleh Camat, dan dukungan anggaran dan personil untuk menjalankan kewenangan yang telah didelegasikan.

Pandangan ini menyerap teori pendelegasian kewenangan dari Wasistiono, (2004) yang mengatakan bahwa pendelegasian sebagian kewenangan pemerintahan dari Bupati/Walikota kepada camat dapat dilaksanakan apabila memenuhi empat prasyarat sebagai berikut: 1) Adanya keinginan politik dari Bupati/Walikota untuk mendelegasikan sebagian kewenangan pemerintahan kepada Camat; 2) Adanya kemaun politik dan Bupati/Walikota dan DPRD Kabupaten/Kota untuk menjadikan kecamatan sebagai pusat pelayanan masyarakat bagi jenis-jenis pelayanan yang mudah, murah, dan cepat; 3) Adanya kelegowoan dari dinas dan atau Lemtekda (lembaga teknis daerah) untuk melimpahkan sebagian kewenangan teknis yang dapat dijalankan oleh Camat, melalui keputusan Kepala Daerah; dan 4) Adanya dukungan anggaran dan personil untuk menjalankan kewenangan yang telah didelegasikan.

Asumsi yang menyatakan bahwa Alokasi Anggaran berpengaruh terhadap Kinerja Kecamatan, merujuk pada pendapat Suparmoko (2000), yang mengatakan bahwa budget pada dasarnya adalah system penyusunan dan pengelolaan anggaran daerah yang berorientasi pada pencapaian hasil atau kinerja. Kinerja tersebut harus mencerminkan efisiensi dan efektivitas pelayanan publik, yang berarti harus berorientasi pada kepentingan publik. Merupakan kebutuhan masyarakat daerah untuk menyelenggarakan otonomi secara luas, nyata dan bertanggung jawab dan otonomi daerah harus dipahami sebagai hak atau kewenangan masyarakat daerah untuk mengelola dan mengatur urusannya sendiri. Aspek atau peran pemerintah daerah tidak lagi merupakan alat kepentingan pemerintah pusat belaka melainkan alat untuk memperjuangkan aspirasi dan kepentingan daerah. 
Asumsi yang menyatakan bahwa kepemimpinan berpengaruh terhadap kinerja kecamatan, merujuk pada pendapat Budiman (dalam Simorangkir, 2004) yang mengatakan bahwa kepemimpinan merupakan seni untuk mendorong kinerja dan motivasi sumber daya organisasi menuju pada tercapainya tujuan, visi, dan misi organisasi. Dalam pandangan ini, Budiman mengatakan bahwa, "kepemimpinan sebagai seni mendorong orang lain untuk mengerjakan yang diinginkan pemimpin agar dikerjakannya”. Seni merupakan suatu upaya bagaimana cara seorang pemimpin untuk mendorong orang lain mengerjakan sesuatu yang diinginkannya.

Dengan dukungan pendapat tersebut, selanjutnya variabel Kepemimpinan dipandang sebagai suatu rangkaian interaksi sosial di antara Camat dengan Perangkat Kecamatan yang berlangsung dalam pelaksanaan tugas dan fungsi Kantor Kecamatan yang terungkap dari bimbingan dan arahan yang diberikan Camat, perilaku hubungan Camat dengan Perangkat Kecamatan, dan level kesiapan perangkat kecamatan. Pandangan ini menyerap teori kepemimpinan situasional dari Hersey \& Blanchard (1995) yang mengatakan bahwa kepemimpinan situasional didasarkan atas hubungan antara (1) kadar bimbingan dan arahan (perilaku tugas) yang diberikan pemimpin; (2) kadar dukungan sosio emosional (perilaku hubungan) yang disediakan pemimpin dan (3) level kesiapan yang diperlihatkan pengikut dalam pelaksanaan tugas, fungsi, atau tujuan tertentu.

Berdasarkan teori kinerja, Prawirosentono (1997) mengatakan bahwa kinerja Organisasi adalah penampilan suatu proses kerja dalam organisasi yang meliputi perilaku para pelakunya (atasan dan bawahan, pegawai/pekerja), proses pekerjaan serta hasil pekerjaan yang dicapai, maka variabel Kinerja Kecamatan dikonseptualisasikan sebagai kinerja organisasi Kantor Kecamatan dalam pelaksanaan tugas dan fungsi kecamatan yang terungkap dari perilaku hubungan atasan dan bawahan dalam melaksanakan pekerjaan; proses pekerjaan yang dilaksanakan, dan hasil pekerjaan yang dicapai.

Berdasarkan urian di atas, maka hipotesis penelitian ini adalah sebagai berikut:

1. Besarnya pengaruh Pelimpahan Wewenang terhadap Kinerja Kecamatan ditentukan oleh Keinginan politik Bupati untuk mendelegasikan sebagian kewenangan pemerintahan kepada Camat, Kemauan politik Bupati untuk menjadikan kecamatan sebagai pusat pelayanan masyarakat, Kelegowoan lembaga teknis daerah untuk melimpahkan sebagian kewenangan teknis yang dapat dijalankan oleh Camat, Dukungan anggaran dan personil untuk menjalankan kewenangan yang telah didelegasikan. 
2. Besarnya pengaruh Alokasi Anggaran terhadap Kinerja Kecamatan ditentukan oleh Komprehensif dan Disiplin, Fleksibilitas, Terprediksi, Kejujuran, Informasi, Transparansi dan Akuntabilitas.

3. Besarnya pengaruh Kepemimpinan terhadap Kinerja Kecamatan ditentukan oleh Bimbingan dan arahan yang diberikan Camat, Perilaku hubungan Camat dengan Perangkat Kecamatan, Level kesiapan perangkat kecamatan.

\section{METODE}

Penelitian ini menggunakan pendekatan kuantitatif (William, 2007; Yusuf, 2016; Sugiyono, 2017). Teknik pengumpulan data yang digunakan dalam penelitian ini adalah penyeberan kuesioner kepada 286 responden yang ditarik dari 1003 orang populasi dengan menggunakan stratified random sampling technique (Cochran, 2007). Jumlah variabel yang diteliti dalam peneltian ini terdiri dari 4 variabel yaitu pelimpahan wewenang sebagai variabel bebas pertama (X1), alokasi anggaran sebagai variabel bebas kedua (X2), kepemimpinan sebagai variabel bebas ketiga (X3), dan kinerja kecamatan sebagai variabel dependent (Y).

Variabel pelimpahan wewenang diturunkan menjadi emat dimensi analisis: (1) Dimensi keinginan politik Bupati untuk mendelegasikan sebagian kewenangan pemerintahan kepada Camat, (2) Dimensi kemauan politik Bupati untuk menjadikan kecamatan sebagai pusat pelayanan masyarakat, (3) Dimensi kelegowoan lembaga teknis daerah untuk melimpahkan sebagian kewenangan teknis yang dapat dijalankan oleh Camat, dan (4) Dimensi dukungan anggaran dan personil untuk menjalankan kewenangan yang telah didelegasikan. Keempat dimensi tersebut dikembangkan menjadi 12 indikator penelitian untuk dijadikan 12 item kuesioner dengan Skala Likert guna disampaikan kepada para responden yang menjadi sampel penelitian.

Variabel alokasi anggaran diturunkan enam dimensi kajian: (1) Dimensi Komprehensif dan disiplin, (2) Dimensi Fleksibilitas, (3) Dimensi Terprediksi, (4) Dimensi Kejujuran, (5) Dimensi Informasi, (6) Dimensi Transparansi dan Akuntabilitas. Keenam demensi kajian kemudian dikembangkan menjadi 18 indikator penelitian untuk dijadikan 18 item kuesioner dengan Skala Likert guna disampaikan kepada para responden yang menjadi sampel penelitian.

Variabel kepemimpinan diturunkan tiga dimensi kajian yaitu: (1) Dimensi bimbingan dan arahan yang diberikan Camat, (2) Dimensi perilaku hubungan Camat dengan Perangkat 
Kecamatan, dan (3) Dimensi level kesiapan perangkat kecamatan. Ketiga demensi kajian kemudian dikembangkan menjadi 12 indikator penelitian untuk dijadikan 12 item kuesioner dengan Skala Likert guna disampaikan kepada para responden yang menjadi sampel penelitian.

Variabel Kinerja Kecamatan diturunkan tiga dimensi kajian: (1) Dimensi perilaku hubungan atasan dan bawahan dalam melaksanakan pekerjaan; (2) Dimensi proses pekerjaan yang dilaksanakan, dan (3) Dimensi hasil pekerjaan yang dicapai. Ketiga demensi kajian kemudian dikembangkan menjadi 12 indikator penelitian untuk dijadikan 12 item kuesioner dengan Skala Likert guna disampaikan kepada para responden yang menjadi sampel penelitian.

Data yang diperoleh melalui pembagian kuesioner selanjutnya diolahan dan dianalisis sesuai dengan tujuan penelitian yang telah di tetapkan. Dalam penelitian ini metode analisis yang digunakan adalah analisis kuantitatif dengan Structural Equation Modelling (SEM) dengan Software Amos 9.0. Structural Equation Model (SEM) adalah suatu tekhnik statistik yang proses pengolahannya secara simultan melibatkan kekeliruan pengukuran, variabel indikator dan variabel laten. Variabel laten adalah variabel yang tidak dapat diukur secara langsung sehingga variabel tersebut dibentuk atau dijelaskan oleh variabel indikator (observable variable) (Bachrudin \& Harapan, 2003; Ghozali, 2006).

\section{HASIL DAN PEMBAHASAN}

1. Analisis Pengaruh Pendelegasian Wewenang Terhadap Kinerja Kecamatan di Kabupaten Garut

Besarnya pengaruh Pelimpahan Wewenang terhadap Kinerja Kecamatan di Kabupaten Garut mencapai 0,754, masuk kategori kuat dan signifikan. Besarnya pengaruh Pelimpahan Wewenang terhadap Kinerja Kecamatan tersebut ditentukan oleh Keinginan politik Bupati untuk mendelegasikan sebagian kewenangan pemerintahan kepada Camat, Kemauan politik Bupati untuk menjadikan kecamatan sebagai pusat pelayanan masyarakat, Kelegowoan lembaga teknis daerah untuk melimpahkan sebagian kewenangan teknis yang dapat dijalankan oleh Camat, Dukungan anggaran dan personil untuk menjalankan kewenangan yang telah didelegasikan. Adanya pengaruh yang demikian itu menunjukkan bahwa di antara Pelimpahan Wewenang dan Kinerja Kecamatan terbentuk suatu hubungan kausalitas yang bermakna: apabila Pelimpahan Wewenang ditingkatkan atau meningkat maka secara stimulan peningkatan Pelimpahan Wewenang tersebut diikuti dengan peningkatan 
Kinerja Kecamatan. Oleh sebab itu, peningkatan Kinerja Kecamatan di Kabupaten Garut bisa ditingkatkan dengan cara meningkatkan, memperbaiki, mengoptimalkan 12 indikator Pelimpahan Wewenang.

Dua belas indikator Pelimpahan Wewenang yang dimaksud adalah berikut: (1) Kewenangan di bidang pengoordinasian, (2) Kewenangan di bidang pengawasan, (3) Kewenangan di bidang perizinan, (4) Pelayanan perizinan, (5) Pelayanan pendidikan, (6) Pelayanan kesehatan, (7) Perencanaan teknis pekerjaan fisik, (8) Pelaksanaan teknis pekerjaan fisik, (9) Pengawasan teknis pekerjaan fisik, (10) Dukungan alokasi anggaran kinerja, (11) Dukungan alokasi anggaran kegiatan, (12) Dukungan sumber daya aparatur.

Optimalisasi pelimpahan wewenang Bupati kepada Camat yang demikian itu dilakukan dengan cara mengoptimalkan dukungan alokasi anggaran kinerja, dukungan alokasi anggaran kegiatan, dan dukungan sumber daya aparatur. Optimalisasi dukungan sumber daya tersebut dilakukan dalam rangka menjadikan Camat sebagai middle manager pemerintahan yang berperan mengoptimalkan hubungan Kepala Daerah dengan Kepala Desa dalam mengimplementasikan kebijakan desentralisasi dan otonomi daerah di Kabupaten Garut.

\section{Analisis Pengaruh Alokasi Anggaran Terhadap Kinerja Kecamatan di Kabupaten Garut}

Besarnya pengaruh Alokasi Anggaran terhadap Kinerja Kecamatan di Kabupaten Garut mencapai 0.651, masuk kategori kuat dan signifikan. Besarnya pengaruh Alokasi Anggaran terhadap Kinerja Kecamatan tersebut ditentukan oleh komprehensif dan disiplin, fleksibilitas, terprediksi, kejujuran, informasi, transparansi dan akuntabilitas. Adanya pengaruh yang demikian itu menunjukkan bahwa di antara Alokasi Anggaran dan kinerja kecamatan terbentuk suatu hubungan kausalitas yang bermakna: apabila Alokasi Anggaran ditingkatkan atau meningkat maka secara stimulan peningkatan Alokasi Anggaran tersebut diikuti dengan peningkatan kinerja kecamatan. Oleh sebab itu, peningkatan kinerja kecamatan di Kabupaten Garut bisa ditingkatkan dengan cara meningkatkan, memperbaiki, mengoptimalkan 18 indikator Alokasi Anggaran.

Delapan belas indikator Alokasi Anggaran yang dimaksud adalah berikut: (1) komprehensif alokasi anggaran, (2) ketepatan alokasi anggaran, (3) disiplin alokasi anggaran, (4) fleksibelitas perencanaan alokasi anggaran, (5) fleksibelitas pelaksanaan alokasi anggaran, (6) fleksibelitas penatausahaan alokasi anggaran, (7) prediksi indicator kinerja 
alokasi anggaran, (8) prediksi capaian indicator kinerja alokasi anggaran, (9) prediksi optimalisasi alokasi anggaran, (10) kejujuran dalam perencanaan alokasi anggaran, (11) kejujuran dalam penggunaan alokasi anggaran, (12) kejujuran dalam pelaporan penggunaan anggaran, (13) pengaturan informasi alokasi anggaran, (14) penyediaan informasi alokasi anggaran, (15) pelayanan informasi alokasi anggaran, (16) transparansi penyaluran alokasi anggaran, (17) transparansi penggunaan alokasi anggaran, dan (18) akuntabilitas penggunaan alokasi anggaran.

Dengan dinamika hubungan kinerja yang demikian itu maka akuntabilitas penggunaan alokasi anggaran kecamatan hendaknya dapat ditingkatkan dengan cara meningkatkan akuntabilitas penggunaan alokasi anggaran kecamatan. Peningkatan ini bertujuan agar kinerja anggaran kecamatan di Kabupaten Garut semakin meningkat untuk meningkatkan transparansi dan akuntabilitas kinerja anggaran berbagai kebijakan, program dan kegiatan pemerintahan, pembangunan, pemberdayaan masyarakat dan pelayanan publik di tingkat kecamatan serta kelurahan dan desa.

Peningkatan kinerja alokasi anggaran kecamatan perlu dilembagakan menjadi $E$ Budgeting System Kecamatan yang teraplikasi ke seluruh jaringan kinerja Organisasi Perangkat Daerah dan mudah diakses masyarakat. Peningkatan kinerja alokasi anggaran kecamatan yang demikian itu mendukung terwujudnya E-Budgeting System kecamatan sebagai bagian integral aplikasi E-Government di Kabupaten Garut.

\section{Analisis Pengaruh Kepemimpinan Terhadap Kinerja Kecamatan di Kabupaten}

\section{Garut}

Besarnya pengaruh Kepemimpinan terhadap Kinerja Kecamatan di Kabupaten Garut mencapai 0.655, masuk kategori kuat dan signifikan. Besarnya pengaruh Kepemimpinan terhadap Kinerja Kecamatan tersebut ditentukan oleh Bimbingan dan arahan yang diberikan Camat, Perilaku hubungan Camat dengan Perangkat Kecamatan, danLevel kesiapan perangkat kecamatan. Adanya pengaruh yang demikian itu menunjukkan bahwa di antara Kepemimpinan dan Kinerja Kecamatan terbentuk suatu hubungan kausalitas yang bermakna: apabila Kepemimpinan ditingkatkan atau meningkat maka secara stimulan peningkatan Kepemimpinan tersebut diikuti dengan peningkatan Kinerja Kecamatan. Oleh sebab itu, peningkatan Kinerja Kecamatan di Kabupaten Garut bisa ditingkatkan dengan cara meningkatkan, memperbaiki, mengoptimalkan 12 indikator Kepemimpinan. 
Dua belas indikator Kepemimpinan dimaksud adalah berikut: (1) Bimbingan Camat kepada pimpinan perangkat kecamatan, (2) Bimbingan Camat kepada staf kecamatan, (3) Arahan Camat dalam pelaksanaan kebijakan, (4) Arahan Camat dalam pelaksanaan kegiatan, (5) Hubungan Camat dengan pimpinan perangkat kecamatan, (6) Hubungan Camat dengan staf kecamatan, (7) Hubungan antar pimpinan perangkat kecamatan, (8) Hubungan antar staf kecamatan, (9) Kesiapan pimpinan perangkat kecamatan, (10) Kesiapan masing-masing urusan kecamatan, (11) Kesiapan masing-masing seksi kecamatan, dan (12) Kesiapan staf kecamatan.

Bimbingan dan arahan Camat; hubungan Camat dengan perangkat kecamatan; dan kesiapan staf kecamatan perlu ditingkatkan agar menjadi faktor penguat kepemimpinan birokrasi pemerintahan. Peningkatan kepemimpinan birokrasi pemerintahan yang demikian itu dapat meningkatkan efektivitas kepemimpinan pemerintahan di tingkat kecamatan. Peningkatan efektivitas kepemimpinan pemerintahan tersebut dapat berpengaruh positif terhadap efektivitas kepemimpinan birokrasi pemerintahan desa dan kelurahan di Kabupaten Garut.

\section{E. KESIMPULAN}

Berdasarkan hasil penelitian diketahui bahwa pelimpahan wewenang, alokasi anggaran dan kepemimpinan berpengaruh positif dan signifikan terhadap kinerja kecamatan di Kabupaten Garut, baik secara parsial maupun secara simultan. Besarnya pengaruh pelimpahan wewenang terhadap kinerja kecamatan mencapai 0,754 ditentukan oleh keinginan politik bupati untuk mendelegasikan sebagian kewenangan pemerintahan kepada camat, kemauan politik Bupati untuk menjadikan kecamatan sebagai pusat pelayanan masyarakat, kelegowoan lembaga teknis daerah untuk melimpahkan sebagian kewenangan teknis yang dapat dijalankan oleh Camat, dukungan anggaran dan personil untuk menjalankan kewenangan yang telah didelegasikan. Besarnya pengaruh alokasi anggaran terhadap kinerja kecamatan yang mencapai 0,651 ditentukan oleh komprehensif dan disiplin, fleksibilitas, terprediksi, kejujuran, informasi, transparansi dan akuntabilitas. Besarnya pengaruh kepemimpinan terhadap kinerja kecamatan yang mencapai 0,655 ditentukan oleh bimbingan dan arahan yang diberikan Camat, perilaku hubungan camat dengan perangkat kecamatan, dan level kesiapan perangkat kecamatan. 


\section{DAFTAR PUSTAKA}

Bachrudin, A., \& Tobing, H. L. (2003). Analisis data untuk penelitian survey dengan menggunakan lisrel 8. Bandung: Jurusan Statistika, FMIPA, UNPAD.

Cochran, W. G. (2007). Sampling techniques. John Wiley \& Sons.

Ghozali, I. (2008). Structural Equation Modeling: Metode Alternatif dengan Partial Least Square (PLS). Semarang: Badan Penerbit Universitas Diponegoro.

Hersey, P., \& Blanchard, K. (1985). Manajemen Perilaku Organisasi. Jakarta: Erlangga.

Kaho, J. R. (2002). Prospek Otonomi Daerah di Negara Republik Indonesia. Jakarta: Rajawali Press.

Ndraha, T. (2011). Kybernology (Ilmu Pemerintahan Baru). Jakarta: Rineka Cipta.

Prawirosentono, S. (1997). Kebijakan Kinerja Karyawan. Yogyakarta: BPFE.

Robbins, S. P. (1994). Organization Theory: Structure, Design and Applications. Jakarta: Arcan.

Simorangkir, O. P. (2004). Pengantar Lembaga Keuangan Bank Dan Non Bank. Bogor: Ghalia Pustaka.

Straus, A., \& Corbin, J. (2007). Dasar-Dasar Penelitian Kualitatif; Tata Langkah dan TeknikTeknik Teoritisasi Data. Yogyakarta: Pustaka Pelajar.

Stoner, J. A. F., \& Wankel, C. (1996). Manajemen. Jakarta: Intermedia.

Sugiyono. (2017). Metode Penelitian Kuantitatif, Kualitatif dan R\&D. Bandung: Alfabeta.

Suparmoko, M. (2000). Keuangan Negara Dalam Teori dan Praktek. Yogyakarta: BPFE UGM.

Sutarto. (1995).Dasar-dasar Organisasi. Yogyakarta: Gadjah Mada University Press.

Terry, G. R. (1960). Office System and Procedurs. Bombay: Taraporevalaa Publishing Industries Privateaa Limited.

Wasistiono, S. (2001). Menata Ulang Kelembagaan Kecamatan. Pusat Kajian Pemerintahan STPDN. Penerbit PT Citra Pindo, Bandung.

Wasistiono, S. (2004). Modul Optimalisasi Peran dan Fungsi Kecamatan dalam Rangka Meningkatkan Pelayanan Kepada Masyarakat. Bahan Penataran Bagi Camat Seluruh Indonesia, Badan Diklat, Jakarta.

Williams, C. (2007). Research methods. Journal of Business \& Economics Research $(J B E R), 5(3)$.

Yusuf, A. M. (2016). Metode Penelitian Kuantitatif, Kualitatif \& Penelitian Gabungan. Jakarta: Prenada Media. 